\title{
International Donor Agencies and Electoral Support in Nigeria's Fourth Republic (1999-2015): The Missing Link
}

\author{
Babayo Sule \\ Department of Political Science, Faculty of Humanities Management and Social Sciences \\ Federal University Kashere, Gombe State, Nigeria \\ Tel: 234-703-865-3490Ｅ-mail: babayosule@gamil.com
}

Hamza Sule Wurobokki (Corresponding author)

Nigerian Police Pension Limited

Louis Edet House Abuja, Nigeria

Usman Sambo

Registry Department, Federal University Gashua

Yobe State Nigeria, Nigeria

Received: December 17, 2017

Accepted: January 14, 2018 Published: March 30, 2018

doi:10.5296/ijssr.v6i1.12320

URL: http://dx.doi.org/10.5296/ijssr.v6i1.12320

\begin{abstract}
International donor agencies are international organisations that operate globally and promote certain values such as democracy, good governance, conflict resolution, humanitarian aid and support and overall global agenda. This paper is an attempt to examine the role of international donor agencies in supporting electoral process in Nigeria from 1999 to 2015 particularly the missing links from the previous studies in terms of their activities in the country. The problem is the nature and method of operation of the international agencies in supporting elections in Nigeria which failed to achieve the desired result. The paper used a
\end{abstract}


qualitative method of data analysis where primary and secondary sources were used. The in-depth interview was conducted with some selected senior officials from the international donors in Nigeria, INEC officials and civil societies in addition to academicians. The secondary source was the used of documented data and materials on the subject matter. The data obtained were analysed using simple statistical analysis such as tables and charts. The research discovered that international donor agencies did not impact much on financing of elections in Nigeria as the country is rich enough to finance her elections comfortably but, they contributed in the process through provisions of technical support to INEC staff, civil societies and weak groups but it was not adequate to ensure a transparent election in the country. The research recommends for a holistic approach that will avoid suspicion locally and be a community-driven and indigenous in nature by the donors to ensure success at the local level.

Keywords: International Donor, Election, Civil Societies, Organisation, Democracy

\section{Introduction}

Election is one of the major principles of a sound and healthy democratic system anywhere in the world. It is simply a peaceful means in which power is transferred from one democratically elected government to another thereby leading to positive continuity and freedom of choice willingly for the electorates (Mahajan, 2012:328). Election has recently become an international concern with the advanced democratic states using the platform of international organisations to foster and promote democratic governance especially the aspect of the election. The international donor agencies in collaboration with civil societies have been pushing for electoral support globally and most especially in emerging democracies (Abdullahi, 2015). One of these developing democracies that have been receiving attention and support from international donor agencies for electoral conduct in Nigeria.

Nigeria has been receiving foreign democratic assistance since the inception of the Fourth Republic in 1999 through different international agencies (Bariledum et al., 2016). These international organisations are mainly from the US and other developed countries such as UNDP and its umbrella organisations under it. The organisations are often engaged in the act of either monitoring of elections or providing financial and technical support to the electoral body, civil societies and other specifically targetted groups in the country. This paper discussed the role of donors in electoral support in terms of election observation and services as well as financial support and the missing link that has been hindering the organisations from realizing their set objectives. The aim is to proffer alternatives different from the existing ones for an improvement and to provide a missing gap in the existing works in this area of knowledge.

\section{Methodology}

The paper used a qualitative method of data collection and analysis. Qualitative methodology is the used of both primary and secondary sources of data for research where a qualitative data was obtained from words, information and other sources that can be interpreted within a given context of study and meaning (Pierce, 2008:112). It is a paradigm for research where a 
rich small data is collected from varieties of sources and coded for extraction of meaning and analysis as well as interpretation (Creswell, 2014:13).

Qualitative data often consist of five major types: narrative; ethnography; phenomenology; case study and grounded theory (Flick, 2009:76). This research is a case study and particularly what is called a particularistic case study because the study involved a specific area and an event within a given time frame (Flick et al. 2004:64). The data collection involves both the primary and secondary sources. The primary source of data is an in-depth personal interview with selected informants from five categories; 4 senior officials of international donor agencies residing in Nigeria, 3 senior officials from Independent National Electoral Commission (INEC), 3 academicians, 4 members of different civil societies and 5 from some selected groups for focus group discussion in Abuja making a total of 19 informants. Other primary source involved documented reports and materials from the government. The secondary source is the use of available sources including books, journals, reports and internet sources on the subject matter of study.

The data obtained from the field was analysed using content analysis and other simple statistical sources such as tables and charts. The content analysis used many works, charts, documented reports, and words from the interview and established a meaning for the analysis and interpretation. Where necessary, tables or charts were established and a model to explain the flow of donor activities in supporting electoral process in Nigeria.

\section{Theoretical Framework: Poliarchy Theory of Democracy}

The work adopted the Poliarchy Theory of international democracy and democratisation as advanced by Dahl and expanded by William. It is thoroughly discussed below.

\subsection{Origin of the Theory}

The theory adopted for this work is the Robert Dahl's Polyarchy Democracy and the expanded Polyarchy Democratic Principles at international level by William I Robinson. The concept of Polyarchy was developed by American Political Scientist Robert Dahl to express the proper acquisition and application of democratic institutions within a political system that leads to the involvement of plural actors in democratisation process (Dahl, 2006:72). Democracy is an electoral representation through a well organised credible and accepted elections and representative government. Polyarchy developed an empirical definition of democratisation and it has referred to a process by which a set of institutions that can be perceived as an ideal type of democratic governance are formed (Dahl, 2006:76). Therefore, public control of democracy is necessary and authority should be exercise by societal institutions, organisations and civil societies. Dahl (2006:79) emphasised that the extent to which these societal actors mentioned above can operate autonomously and independently from the state enhance the democratic quality of a state.

The theory was advanced by Robinson (2013) in what he termed promoting Polyarchy 20 years after Robert Dahl in his attempt to advance and promote the theory of its applicability at the international stage. He cited that he advanced the theory in 1996 to have included international Polyarchy principles of democracy and 20 years after that he still feels the need 
to re-assert the status (Robinson, 2013).

\subsection{Basic Assumptions}

It is believed that the institutionalisation of democratic institutions and processes is a pre-requisite for Polyarchy these institutions according to Dahl (2006:87) include:

1. Universal suffrage and the right to run for public office;

2. Free and fair periodic elections for all eligible citizens;

3. Availability of freedom of speech and the guarantee of protection;

4. Existence and a free flow of information independent of government;

5. Right to establish formal and informal autonomous organisations;

6. Representative and responsible government and accountability of government.

The global Polyarchy is the process whereby US from 1980s continue with an attempt at democratisation process globally. Internal political and electoral intervention has been perpetrated by US through international agencies for many decades in the name of democracy promotion (Robinson, 2013). As capitalist globalisation advanced, global elites forged consensus around trans-national agenda of neo-liberalism and Polyarchy democracy. As countries and regions have integrated into global capitalism, they have seen the rise of new trans-nationally oriented elites organised in business associations, political parties, civil groups, the mass media and so on that are supported by United States and Western political intervention programmes conducted under the pretext of democracy promotion (Robinson, 2013). Thus, democracy promotion agenda seeks to recruit local elites that can conform to the international elite agenda of capitalist interest and eliminate resistance from local elite that are against their interest. They also seek to contain the masses and restrain them from becoming politicised and mobilised on their own independent of or in opposition to the trans-national elite interest by incorporating them unconsciously into the political order that these programmes seek to establish and to influence political institutions such as electoral body in determining the direction s of the emergence of ruling elite (Robinson, 2013).

\subsection{The Strengths of the Theory}

The theory is a contribution to democratic theory and a powerful incentive for empirical analysis. The theory and its concept has become one of the widely used terms in Political Science for many decades. The theory is a realistic explanation of the current international agenda practically by the Western powers without any ambiguity.

\subsection{The Weaknesses and Criticisms of the Theory}

The theory is weak in its assumptions that all world democracies must be anchored along the line of Western democracies particularly American liberal style before it is considered a Polyarchy in principles. The theory also assumed that Polyarchy principles must be extended globally in which it will be cumbersome for the US and its allies to do so successfully owing to the dynamic nature of global politics. The notion of the theory also that, promotion of Polyarchy and democratic institutionalisation globally is all about the interest of 
trans-national elite is defective in the sense that some international donor agencies are independent of the state as proposed by Dahl in his earlier Polyarchy in their nature and international operations.

\subsection{Applicability of the Theory within the Context of the Work}

The theory of Polyarchy as advocated by Dahl (2006) and further established by Robinson (2013) on democratic governance and institutionalisation of democracy through its promotion globally clearly explain the operations and activities of international donor agencies globally and in Nigeria specifically in electoral support. It can explain how the donor agencies promote the Western liberal electoral agenda and process in Nigeria despite the financial strengths of Nigeria to cater for her election appropriately without any need for intervention. The aim is suspicious by locals and even some INEC officials and policymakers. The purpose of the Western donor agencies is understood as expressed by Robinson (2013) to manipulate the local elites and the populace to cooperate with trans-national elites through determining who shall emerge as winner in the sponsored electoral process by the donors. Also, the position of Dahl (2006) of the fostering of democratic institutions and free and fair elections as one of the major assumptions of Polyarchy explains the way in which the donor electoral support fits in this work.

\section{Literature Review}

This section discussed major issues related to the themes of the work such as the background of the Nigeria's Fourth Republic, overview of international donor agencies globally, emergence of international donor agencies in Nigeria, electoral donor agencies in Nigeria and electoral donor agencies and electoral support in Nigeria. The scholastic views were reviewed critically and contributions were made in filling the gap for contribution to knowledge.

\subsection{Background of Nigeria's Fourth Republic}

The Nigeria's Fourth Republic started in 1999 after many decades of military regime which led to setback in democratic governance. The Military Regime of General Abdulsalami Abubakar took over power in 1998 after the death of General Sani Abacha and quickly fulfilled its promise of a short transition to democratic rule 1999. A short transition timetable was drafted from June 1998 to May 1999 and it was successfully implemented. Just like the previous processes, the Abdulsalami Regime followed the previous transition processes except that his own was too quick and there was no constituent assembly. A committee was just constituted which studied the 1979 Constitution and the 1995 drafted Constitutions and made some recommendations which were hurriedly implemented. Another committee was formed that collated the views of Nigerians and submitted it to the Provisional Ruling Council (PRC) which approved a draft that was later promulgated Decree 24, 1999 known as the 1999 Constitution by May. The new electoral body, the Independent National Electoral Commission (INEC) registered three political parties out of the twenty-six that applied. The registered political parties were All People's Party (APP), Alliance for Democracy (AD) and People's Democratic Party (PDP) (Lucky, 2017).

Nigeria's Fourth Republic (1999-date) is the longest democratic governance and Republic in 
the country which recorded five (5) successful General Elections in 1999, 2003, 2007, 2011 and 2015 with many multiple political parties emerging into the arena but the PDP dominated the ruling at both national and state levels for straight sixteen years. There were allegations of election rigging and malpractices, vote buying, violence, intimidation and strangulation of opposition, political thuggery and subversion of democratic principles. All these emanated from the nature of the political culture of the country of ethnoreligious politics and power domination for primitive accumulation of wealth and the faulty transition programme which was managed by the military with candidates anointed and a genuine choice was avoided deliberately (Adeosun, 2014, Oyediran \& Nweke, 2014; Usman \& Avidine, 2016).

However, the Fourth Republic recorded a significant improvement in democratic governance in terms of the emergence of civil societies, opposition politics to a minimal extent in the early years of the Republic and stronger opposition in later years, the presence of international agencies that support electoral activities and proper democratisation process. The improvement led to the emergence of a party (PDP) which became national in orientation as against the previous Republics where political parties were ethnic in outlook and regional in nature. The party (PDP) dominated politics at the national and local level for four periodic elections. The Fourth Republic also witnessed the emergence of a strong opposition party (APC) that wrestled power from the ruling PDP after sixteen (16) years. In addition, it was the first time that Nigerian electoral process witnessed increased activities of international donor support towards a better election and democratisation (Adetula, 2010).

\subsection{Perspective on International Donor Agencies}

International donor agencies are powerful organisations in development aid and international development in general. They supplied aid to developing countries in many perspectives. They offer substantial assistance for humanitarian assistance and development activities and have increasingly emerged as influential factors in policy making and policy processes in the global governance (Morton, 2013). International donor agencies have multiple autonomous national offices based in many OECD and other developing countries and they also operate as members of global consortia, confederations and other affiliations that carry development programmes through regional and national offices in developing countries (Morton, 2013).

The international donor agencies are larger in their operations in terms of budget, staffing and activities. For instance, an average annual revenue of a middle-level donor agency like World Vision Australia was \$345 million and many other donors budgeted higher for development programmes and humanitarian support in developing the world. The major objectives of donor agencies globally involve: fight against worldwide poverty; protection of human rights; eradication of diseases; democratic governance; education; climate change and other global developmental issues (Morton, 2013).

International donors existed in many forms for many centuries but their ascendency to prominence in international development is in the 1980s and their numbers dramatically increased in the 1990s. The United Nations estimated that there were 35, 000 stronger donor organisations as at 2000 with a heavy budget of $\$ 23$ billion total aid and have increased to $\$ 78.6$ billion in the year 2004 (Lewis, 2009). The international donors have basically three 
main components as implementers; catalysts and partners. The implementer role involved the mobilisation of resources to provide goods and services to those who need them. The catalysts action is the inspiration, facilitation and contribution towards improved thinking and action to promote social transformation. This activity may be directed towards individuals, organisations, institutions and governments. The role of the partner is to liaise with government, organisation and other agencies on joint activities such as electoral conduct and educational programmes (Lewis, 2009).

The Commission on Science and Technology Development in the South (COMSATS) in 2007 compiled a directory of international donor and development organisations that are currently famous and active on the world stage for development aid to various sectors such as democratic promotion, economic sustainability, healthcare foundations, educational foundations, human rights organisations etc. The directory presented about 66 of them out of which this study found the most relevant to have included: Canadian International Development Agency (CIDA); Department for International Development (DFID); MacArthur Foundation; Rockefeller Foundation; United Nations Development Programme (UNDP) and United State Agency for International Development (USAID). These were found to be most important because they are actively engaged in donor activities and electoral support in Nigeria since 1999. Other donor agencies that were also active in Nigerian State but were not mentioned in this work include the United Kingdom Agency for International Development (UKAID), International Federation for Electoral System (IFES), National Democratic Institute (NDI), International Republican Institute (IRI), European Union (EU) and European Commonwealth Observer Mission (EUCOM).

\subsection{International and Electoral Donor Agencies in Nigeria: An Overview.}

During the last decades of military rule in Nigeria (the 1990s), there were intensified pressures from the international community on democratisation. This emanated from the annulment of June 12, 1991, Presidential Election. From 1993 to 1999, the international donors' activities in supporting democratisation in Nigeria emerged in which the European Union, the United States and other international bodies put a limited sanction on Nigeria and drastically limit diplomatic relationship. The Commonwealth countries suspended Nigeria's membership and the country came under heavy criticism by the United Nations and Organisations of African Unity for an alleged human rights violation. The EU suspended project development cooperation in Nigeria. But, even with the sanction, the humanitarian aids activities by the international donors continued. The European Parliament provided a budget of EUR 7 million in 1998 and 1999 to support human rights and democracy in Nigeria. Many Nigerian NGOs and human rights organisations benefitted from the donation by the EU Parliament (Adetula, Kew \& Kwaja, 2010).

The above analyses indicated clearly that the international donor agencies have been active and present in Nigerian territory even before the inception of the Fourth Republic and they have been actively engaged in democratic support and other humanitarian services. Their activities were later expanded to have involved support to electoral process and conduct when the democratic rule gained ground for deepening and consolidation of democracy. In 
mid-June 1998, the military administration of General Abdulsalami Abubakar set a quick transition timetable to democracy and in response towards this positive development, the international organisations and international community restored all assistance to the country instantly. The bilateral and multilateral donors provided aids to support the political transition. They provided technical assistance to key institutions including Independent National Electoral Commission (INEC), State Independent Electoral Commissions (SIECs), political parties, associations and civil society groups. Donor activities in the areas of democracy promotion and good governance increased significantly (Adetula et al. 2010). Many vital international donor organisations surfaced from 1999 in supporting electoral process in Nigeria including USAID, UKAID, DFID, CIDA, IFES, NDI, IRI, EU providing joint donor basket fund for electoral support to date.

\subsection{International Donor Agencies and Electoral Support in Nigeria's Fourth Republic}

During the 1999 and 2000, the EDF Committee provided financing proposals to a maximum value of EUR 100 million for democratic support across the country. The United States for International Development (USAID) is the largest bilateral democratic donor in Nigeria. In 2009, USAID estimated that it will provide USD17.552 million (N6, 318, 684, 724.84 billion) for various forms of democratic assistance in Nigeria. In 2008, USAID spent USD13.448 million (N4, 841, 265, 630.64 billion) which is lesser than the total budget of 2007 USD18.790 million (N6, 764, 304, 622.04 billion). Other key donors in Nigeria are the United Kingdom Department for International Development (DFID) whose funding in 1997 total an amount of GBP 85 million (N40, 624, 568, 500 billion) and GBP 322 million (N153, $895,424,200)$ in 2008. The DFID has a total budget of GBP950 million (N454, 039, 295, 000 billion) for the period 2009 to 2014) and the European Commission with a long-standing interest in supporting elections and human right activities in Nigeria. Other international democratic and election support donors include the World Bank and United Nations agencies particularly the United Nations Development Programme (UNDP). Recently, the Canadian International Agency for Development (CIDA) became active in supporting electoral process, promoting democracy and good governance in Nigeria. There are also few small donors from Japanese International Cooperation Agency (JICA), France, Norway and Germany (Adetula et al., 2010).

The Consortium for Electoral and Political Processes (CEPPS) has been the major platform for USAID's democratic support in Nigeria and it consists of three United States NGOs; the National Democratic Institute (NDI), the International Republican Institute (IRI) and the International Federation for Electoral System (IFES). In 1999, the NDI initiated a programme for legislative support to a total sum of USD4.54 (N1, 634, 383, 928.10 billion). The training included training in the areas of budget analysis, rules and procedure, the role of committees, legislative drafting, constituency relations, civil society engagement and legislative IT resource centre. Another NDI budget of USD6.2 million (N22, 319, 396, 841.28) under the USAID/Nigeria country strategy for 2004 to 2009 was provided for supporting democracy, good governance and electoral process. Also, the USAID provided funds for IFES to provide technical assistance and the electoral support to INEC worth USD4.3 million (N15, 479, 698, 204.35 billion) till December 2003 (Adetula et al. 2010). 
IRI, on the other hand, managed USAID assistance to political parties and civil societies and associations in technical areas. From 1999 to 2003, USAID funded USD2.75 million (N989, 974, 085. 38 billion) to IRI for this purpose alone (Adetula et al. 2010).

The democratic support and electoral support involves funding of elections and provision of technical assistance by different agencies that are involved and they have so far expended a significant amount of money towards that in Nigeria. For instance, United Nations Development Programme (UNDP) presented a total sum of all the monies injected in democratic and electoral support from 2012 to 2013 as follows.

Table 1. International Donor Funding for Democratic Governance and Electoral Support in Nigeria

\begin{tabular}{lll}
\hline Year & International Donor Agency & Amount Contributed \\
\hline $2012-2013$ & All Donors & $\$ 12.5$ million $(\mathrm{N} 4,499,965,270.50$ billion $)$ \\
$2012-2015$ & EU & $\$ 25$ million $(\mathrm{N} 8,999,925,146.38$ billion $)$ \\
$2012-2015$ & DFID & $\$ 10.9$ million $(\mathrm{N} 3,923,966,267.87$ billion $)$ \\
$2012-2015$ & CIDA & $\$ 3$ million (N1, 079, 990, 375.97 billion) \\
$2012-2015$ & UNDP & $\$ 12.6$ million (N4, 535, 960, 297. 47 billion) \\
$2012-2015$ & KOICA & $\$ 230,000$ thousand $(\mathrm{N} 82,799,257.43$ million) \\
Total & & $\$ 64,230,000(23,122,381,345.67$ billion). \\
\hline
\end{tabular}

Source: UNDP 2015

The foreign democratic assistance that is specifically meant for elections conduct alone is managed by USAID and its consortium as mentioned above. Other support can include non-electoral activities and humanitarian services. In this perspective, the electoral donor support amounted to millions of dollars and billions of naira in the Fourth Republic. The democratic assistance and electoral support in this category consist of technical assistance to electoral bodies to improve the administration of elections, support for voters' education and election monitoring by international observers. The US has been assisting Nigerian elections since 1999 with the commencement of the Fourth Republic up to 2015 General Elections. For instance, USAID in partnership with DFID provided $\$ 868.8$ million (N312, 761, 470, 412.58 billion) assistance to improve election management and performance of electoral institution (US Fact Sheet, 2015).

However, the electoral support does not include financing of INEC directly or the electoral processes itself. This is because Nigeria is rich enough to undertake and fund its elections comfortably without any assistance from external donors, unlike many other poor African countries that rely on external donation to conduct their periodic elections. A good example is a comparative analysis of what the electoral body (INEC) spent during the two most recently concluded elections in Nigeria; the 2011 and 2015. The following table indicates what INEC spent during the 2011 and 2015 General Elections alone. 
Table 2. Independent National Electoral Commission (INEC) total Expenditure in 2011 and 2015 General Elections

\begin{tabular}{ll}
\hline Election Year & Amount \\
\hline 2011 & N122.9 billion $(\$ 341,391,620.00$ million $)$ \\
2015 & N92.904 billion $(\$ 258,068,731.20$ million $)$ \\
Total & N215.804 billion $(\$ 599,460,351.20$ million $)$ \\
\hline
\end{tabular}

Source: INEC 2017

Comparatively, this clearly indicates that what INEC spent to conduct two elections only in 2011 and 2015 in the present Fourth Republic by far surpassed the total amount contributed by all donors jointly in supporting electoral activities and conduct in Nigeria. A total sum of $\mathrm{N} 215.804$ billion $(\$ 599,460,351.20$ million) was spent by INEC while the total donations from all organisations between the same period of 2011 to 2015 was $\$ 64,230,000(23,122$, $381,345.67$ billion) according to UNDP (2015). The implications are the international donor electoral support might not possibly have influenced the electoral processes and outcome positively and their relevance towards the elections can be minimal. Also, there might be the feelings from Nigeria that the donors are not wanted in this case because of self-sufficiency. The next section of the work; discussion of data and findings revealed supports this statement from the informants' views and opinions. Thus, there should be areas that the international donors should focus on and which presently they neglected and these areas are the missing links that this work addressed.

\section{Data Analysis and Discussion of Major Findings}

In this section, the data generated was presented and discussed analytically for interpretations and findings. It was discovered from the existing literature above that the international donor agencies have been operating in Nigeria since before the inception of the Fourth Republic and were at the forefront of promoting democratic good governance and supporting electoral conduct with millions of dollars translated into billions in Nigerian currency. It has also been observed above from the scholastic views (Adetula et al., 2010; Abdullahi, 2015; Bariledum et al., 2016) that the amount provided for technical support of electoral conduct and training of electoral body officials as well as support to civil societies were not enough to influence the electoral process in Nigeria and foster democratic good governance because the country is self-sufficient financially in funding the entire electoral process independently without relying on external donors' support unlike many other African countries. This made the objectives of international donors far from realised within the period of study 1999 to 2017 . This paper contributed in presenting the views of the informants on the possible missing links that the international donor agencies should exploit to achieve their objectives of promoting democracy, good governance and credible electoral conduct in Nigeria.

Thus, data were obtained in the following category and it was coded in the table below for easy perception. 
Table 3. List of Selected Informants and their Category

\begin{tabular}{lll}
\hline Category & Informants & Frequency \\
\hline A & International Donor Agencies in Nigeria & 4 \\
$\mathrm{~B}$ & Officials of Independent National Electoral Commission & 3 \\
& (INEC) & \\
$\mathrm{C}$ & Academicians & 3 \\
$\mathrm{D}$ & Members of Civil Societies & 4 \\
E & Focus Group Discussion & 5 \\
Total & Five Categories & 19 \\
\hline
\end{tabular}

Source: Field Survey 2017

The above indicates the categorisation for the informants selected for the interviews that were conducted. Additional information here was the criteria of their selection. The category A of international donor agencies that were chosen emanated from the limited resources and the accessibility in Abuja Nigeria. One of them is from UNDP, another from DFID, another from USAID and the last one is from CIDA; the four major electoral donor supporters in Nigeria in the Fourth Republic. In category B, the INEC officials, former Director Operations, Director Political Party Monitoring Department and Director Finance and Audit Department were selected. In category C; academicians, a Professor of Political from Bayero University Kano who is a specialist in elections and civil societies was chosen, a Professor of Political Science from Ahmadu Bello University Zaria who is a specialist in international relations, particularly international donors, was selected and lastly, a Professor at University of Abuja who is a specialist in Nigerian Government and Politics was selected for the interview.

In category D, there is currently what is called Civil Society Situation Room which includes a membership of $300+$ civil societies in Nigeria that are working closely with INEC in monitoring elections and other democratic activities. Four of them were selected based in Abuja. Finally, category E is the Focus Group Discussion with some selected members of the public from Unity Fountain in Abuja which is a centre for political activities by various groups that always meet on daily basis for one activity or another that is related to elections, democracy and good governance promotion.

The above was the major source of data in addition to the content analysis that was used in the literature and is used here also. The information was presented according to their responses as follows. The informants expressed their views on the role of international donor agencies and what they need to do to achieve their goal of democratisation and credible elections in addition to good governance. In the category A, the views they presented were summarised as follows. 
Table 4. Responses of Informants in Category A on the Successes and Challenges of the international donor in Electoral Support

\begin{tabular}{lll}
\hline Informants A & Successes & Challenges \\
\hline 1 & $\begin{array}{l}\text { Improved elections, voters, Transportation and communication } \\
\text { awareness } \\
\text { Improved civil societies and Corruption and native culture } \\
\text { electoral conduct }\end{array}$ \\
& $\begin{array}{l}\text { Information dissemination and Politicians manipulations and apathy } \\
\text { training } \\
\text { Funding of parties and civil Perception and political culture } \\
\text { societies'training }\end{array}$ \\
\hline
\end{tabular}

Source: Field Work 2017

The above category revealed their successes in their operations in Nigeria to have included improvement in election conduct, increased civic voter education, improvement in the flow of information, training of INEC staff and civil societies as well as public office holders and provision of funding for civil societies. The major challenges include on the other hand transportation into remote areas, language barrier in communication with the natives, corruption in the electoral system which impedes smooth election conduct, activities of politicians, political apathy and negative perception or suspicion of their role in democratisation. The other category revealed the roles and successes of the international donors in their own different way as presented in the table below.

Table 5. Responses of Informants in Category B (Senior INEC Officials) on the Activities of the international donor in Electoral Support

\begin{tabular}{lll}
\hline Questions & $\begin{array}{l}\text { Informants } \\
\text { B (Yes) }\end{array}$ & $\begin{array}{l}\text { Informants } \\
\text { B (No) }\end{array}$ \\
\hline Is there a need for electoral donor support in Nigeria? & 1 & 2 \\
Does the electoral body need any funding externally? & 0 & 3 \\
Do the electoral officials need training from donors? & 2 & 1 \\
Do the international donors influence the electoral conduct? & 1 & 2 \\
Are the voters affected by international donors positively? & 1 & 2 \\
Is the training given to the legislature leading to good governance? & 1 & 2 \\
Are the weak groups influenced by international donors' activities? & 1 & 2 \\
Do the international donors target politicians for better governance? & 1 & 2 \\
Do the international donors achieve their goals so far? & 1 & 2 \\
Have the international donors achieve some significant success? & 1 & 2 \\
Have the international donors met serious challenges? & 3 & 0 \\
\hline
\end{tabular}

Source: Field Survey 2017 


\section{Macrothink

The above table is a response of the three (3) INEC staff (category B) that were interviewed and majority of their views indicated clearly that the international donors played a significant role in the electoral support but to a lesser extent and they are yet to achieve their objectives as most of the informants responded in negative in terms of the needful of what the international donors need to do to influence election and democratic governance in Nigeria. The next group also revealed the same position as expressed below.

Table 6. Responses of Informants in Category C (Academicians) on the Activities of the International donor in Electoral Support

\begin{tabular}{lll}
\hline Questions & \multicolumn{2}{l}{$\begin{array}{l}\text { Informants } \\
\text { Informants }\end{array}$} \\
\hline Is there a need for electoral donor support in Nigeria? & C (No) \\
Does the electoral body need any funding externally? & 2 & 1 \\
Do the electoral officials need training from donors? & 2 & 3 \\
Do the international donors influence the electoral conduct? & 2 & 1 \\
Are the voters affected by international donors positively? & 1 & 2 \\
Is the training given to the legislature leading to good governance? & 1 & 2 \\
Are the weak groups influenced by international donors' activities? & 2 & 1 \\
Do the international donors target politicians for better governance? & 1 & 2 \\
Do the international donors achieve their goals so far? & 1 & 2 \\
Have the international donors achieve some significant success? & 2 & 1 \\
Have the international donors met serious challenges? & 3 & 0 \\
\hline
\end{tabular}

Source: Field Survey 2017

In this category (C Academicians), the informants just like their INEC counterparts above suggested that the international donors have achieved some level of success in their electoral donor support but have not been able to achieve their objective because of what seems to have been the misplacement of priorities. Perhaps, the weak groups and voters should be the major target ahead of electoral body and civil societies as well as politicians.

In the next category (D), the civil societies where four (4) of them were asked, they revealed the following information accordingly. 
Table 7. Responses of Informants in Category D (Civil Societies) on the Activities of the International donor in Electoral Support

\begin{tabular}{|c|c|c|}
\hline Questions & $\begin{array}{l}\text { Informants } \\
\text { D (Yes) }\end{array}$ & $\begin{array}{l}\text { Informants } \\
\text { D (No) }\end{array}$ \\
\hline Have u received fund donations from international donors? & 4 & 0 \\
\hline Did you receive training from international donors? & 4 & 0 \\
\hline If yes above, was the training successful in boosting your activities? & 4 & 0 \\
\hline Have you work coordinately with INEC in elections conduct? & 4 & 0 \\
\hline Were you part of the elections observers in Nigeria? & 4 & 0 \\
\hline Have you been able to reach grassroots and educate voters properly? & 2 & 2 \\
\hline Did your activities improve the electoral conduct in Nigeria? & 3 & 1 \\
\hline Have you met serious challenges in your daily operations? & 4 & 0 \\
\hline Were you being able to influence voters on election conduct? & 1 & 3 \\
\hline
\end{tabular}

Source: Field Survey 2017

As observed by many scholars (Adetula et al., 2010; Bariledum et al., 2016), the international donors provided fund and other technical assistance such as training to civil societies with the aim of making them to reach the grassroots for civic voter education as part of the improvement of the election in general. However, the problem here is they have admitted in the table above that they were not able to reach the grassroots appropriately as most of their activities centred in urban areas. This is where the operations failed to impact as required.

In the last category (E Focus Group Discussion), their views were summarised and presented below on the successes and challenges of the international donor in electoral support in Nigeria.

Table 8. Responses of Informants in Category E (Focus Group Discussion) on the Activities of the International donor in Electoral Support

\begin{tabular}{|c|c|c|}
\hline Informants E & Successes & Challenges \\
\hline 1 & $\begin{array}{l}\text { Training of electoral officials and election } \\
\text { observation }\end{array}$ & $\begin{array}{l}\text { Negative perception from the } \\
\text { locals }\end{array}$ \\
\hline 2 & $\begin{array}{l}\text { Funding of groups and watchdog for fair } \\
\text { elections }\end{array}$ & Corruption from electoral officials \\
\hline 3 & Supporting INEC with equipment and skills & $\begin{array}{l}\text { Communication gap between } \\
\text { communities }\end{array}$ \\
\hline 4 & Training of political parties and politicians & Inadequate funding and training \\
\hline 5 & $\begin{array}{l}\text { Providing vital information for INEC, groups } \\
\text { and voters }\end{array}$ & National sovereignty and politics \\
\hline
\end{tabular}

Source: Field Survey 2017

From the above total sum narrations of all the informants in categories A, B, C, D and E, it is evident that international donors achieved relevant successes in some areas while they failed 
in many areas. The major successes recorded include training of politicians for good governance, INEC officials and civil societies, civic voter education with limitation however to urban areas, provision of technical skills and information to INEC and civil societies, election monitoring and provision of funds for activities of political groups as well as supporting them. This position has been supported by Adetula et al. (2010), Abdullahi (2015) and Bariledum et al. (2016) in their previous works on the subject matter. By implications, all the above successes referred to the promotion of democracy, good governance and improvement in electoral conduct in general. This has been witnessed in the recently concluded 2015 General Elections where the training and technical skills provided by international donors and vital information in addition to advice helped immensely in ushering in a credible election and a situation where the training offered to political parties and politicians led to the emergence of a strong opposition that wrestled power from the ruling PDP which ruled for straight sixteen (16) years.

On the other hand, the major challenges faced by international donors in discharging their responsibilities as identified by the informants in various categories above include among others; transportation of personnel into remote areas which proved to be extremely difficult due to swampy nature of creeks in the south and Sahara desert in the core north, communication gap with natives due to language barrier, negative perception of the activities of international donors leading to suspicion and hostilities from the politicians, INEC staff and local communities, financial strength of Nigeria as a rich country that is self-sufficient to sponsor her election appropriately without any assistance from the donors which drastically limit their influence in the electoral process and conduct, inability to reach the local community for civic voter education and international politics where the ruling class felt insecured with the presence of international observers and international donors. Some of these views were discussed by Adetula et al. (2010) and Bariledum et al. (2016) in their works.

The missing gap here is very clear. Neither the international donors practically identify it nor the scholars that wrote on the field. It is about a shift in focus of the international donors towards influencing the electorates at the grassroots to engage actively in the voting process and to shun the electoral malpractices such as the sponsorship for political thuggery by politicians and vote buying, ballot stuffing, ballot snatching or alteration of the result. The international donors focus on INEC, political parties, politicians and civil societies all in urban centres. They neglect the rural areas where about 70 percent of Nigerian voters came from and where the manipulation of electoral processes take place easily. Since it is very difficult to influence the categories identified in urban centres, the international donors relied heavily on civil societies to reach out to rural people and it is difficult for them to do so. The civil societies in the interview above confessed that they hardly reach local communities as most of their activities are limited to urban centres. This is the area of need that the international donors should have a rethink and consider in their future engagement in Nigeria for democratic promotion and electoral support if they really want to influence the electoral process positively. 


\section{Conclusion and Recommendation}

The paper concludes that the international donors who are supporting electoral process and conduct in Nigeria have been putting their best in funding many democratic activities that will support the promotion of democratisation, good governance and credible elections but the challenges that they are facing have impeded them from realizing their targetted objectives. The paper also concludes that the international donors misplaced priorities in their targets and there is every need to retrace their steps to forge ahead for a better result. The research also concludes that previous studies in this field didn't identify clearly this missing link but, this work identified it and pointed it out to the international donors to refer to in future. Thus, the research recommends the following:

1. The international donors should hire local experts who will penetrate al nooks and crannies in the country for proper intensive civic voter education and political awareness to the electorates at the grassroots level;

2. The international donors should provide a substantial amount of money for production of pamphlets and small books on local languages and lingua franca of each of the six geo-political zones on political awareness and electoral conduct;

3. The international donors should sublime their Western interest and set the Nigerian agenda ahead by identifying culture and peculiarities of the politics by integrating them into their objectives;

4. The Political culture of Nigeria should be studied and the donors should endeavour to drastically curb the influence of money politics;

5. Overall rural development project permanently should also be targetted as poverty, unemployment, hunger, disease, illiteracy and corruption are denying the populace from cooperating towards better and improved elections and

6. Political parties should be trained to be ideological and principled in nature instead of just capture of power for personal benefit.

\section{Acknowledgements}

The research has not been sponsored by any formal organisations except family and friends and personal source. However, a special acknowledgement goes to Dr. Hamza Sule Wurobokki, one of the co-authors for his financial resources and academic contribution in undertaking the field work and sponsorship of materials for the conduct of the research and Dr. Usman Sambo another co-author for his inspiration and motivation in carrying the research.

\section{References}

Abdullahi, A. (2015). Promoting Credible Elections in Developing Countries: International Development Partners and Civil Society Organisations in Nigeria. African Journal of Political Science and International Relations, 9(5), 190-199.

Adetula, V., Kew, D., \& Kwaja, C. (2010). Assessing Democracy Assistance: Nigeria. The United Nations Democracy Fund. 
Adeosun, A. B. (2014). Democracy and Democratic Consolidation in Nigeria's Fourth Republic: Issues and Challenges. IOSR Journal of Humanities and Social Science, 19(10), 05-10.

Bariledum, K., Godpower, N. B., \& Tambari, N. S. (2016). "Foreign Democratic Assistance to Nigeria (1999-201): The Nexus Between Strategy and Elections Results". Global Journal of Political Science and Administration, 14(1), 29-37.

Creswell, J. W. (2014). Research Design, Qualitative, Quantitative and Mixed Methods Approaches. London: Sage Publication.

Dahl, R. (2006). A Preface to Democratic Theory. Chicago: University of Chicago Press.

Directory of International Donor and Development Organisations. (2007). Commission for Science and Technology for Sustainable Development in the South.

Flick, U. (2009). An Introduction to Qualitative Research. London: Sage Publication.

Flick, U., Kardoff, E. V., \& Steinke, I. (2004). A Companion to Qualitative Research. London: Sage Publication.

Lucky, O. O. (2017). Democratic Transition and Consolidation in Nigeria: Trends and Prospects since 1999. International Journal of Politics and Good Governance, 8(8), 1-21.

Mahajan, V. D. (2012). Political Theory. New Delhi: S. Chand Publishers.

Oyediran, P. A., \& Nweke, O. I. (2014). An Appraisal of Nigerian Democratic Journey Between 1999-2014. JORIND, 12(2), 54-66.

Pierce, R. (2008). Research Method in Politics: A Practical Guide. London: Sage Publication.

Robinson, W. I. (2013). Promoting Polyarchy 20 Years Later. International Relations, 27(2), 228-234.

United Nations Development Programme (UNDP). (2015).

US Fact Sheet. (2015).

Usman, S. O., \& Avidine, S. S. (2016). Assessing Democratic Governance in Nigeria's Fourth Republic” European Scientific Journal, 12(29), 142-155.

\section{Copyright Disclaimer}

Copyright for this article is retained by the author(s), with first publication rights granted to the journal.

This is an open-access article distributed under the terms and conditions of the Creative Commons Attribution license (http://creativecommons.org/licenses/by/3.0/). 